\title{
COMUNICACÕES
}

\section{Ocorrência de Xanthomonas campestris pv. vitians em alface, em Minas Gerais}

\author{
Nilvanira Donizete Tebaldi ${ }^{1}$, Olinda Maria Martins ${ }^{2}$, Lara Caroline Borges Moreira Mota ${ }^{3}$
}

${ }^{1}$ Professora Adjunto e ${ }^{3}$ Técnica de Laboratório do, Instituto de Ciências Agrárias, Universidade Federal de Uberlândia, Av. Amazonas s/n, Bloco 2E-121, Campus Umuarama, CEP 38.400-902, Uberlândia, MG, Brazil

${ }^{2}$ EMBRAPA-Cenargen, Parque Estação Biológica/W5 Norte, CEP 70770-900, Brasília, DF, Brazil

Autor para correspondência: Nilvanira Donizete Tebaldi (nilvanira@iciag.ufu.br)

Data de chegada: 09/05/2014. Aceito para publicação em: 10/09/2015.

$10.1590 / 0100-5405 / 2004$

Em 2013, no município de Uberlândia, MG, foram observadas em casa de vegetação, mudas de alface (Lactuca sativa L.) em bandejas, cultivar "Brida", com sintomas de lesões encharcadas, translúcidas, marrons tornando-se negras, podendo coalescer e expandir ao longo da nervura da folha (Figura 1A). A partir de preparações microscópicas do tecido infectado observou-se exsudação de células bacterianas. O isolamento em meio de cultura apresentou o crescimento de uma bactéria com as seguintes características: Gram negativa; oxidação/fermentação: aeróbia estrita; com colônias mucóides, convexas, brilhantes, de coloração amarela em meio de cultura 523 e YDC, após 2 dias, a $28{ }^{\circ} \mathrm{C}$; crescimento a $40{ }^{\circ} \mathrm{C}$; oxidase, hidrólise do amido, asparagina como única fonte de carbono e nitrogênio, produção de ácidos à partir do arabinose, todos negativos; levan, catalase; utilização de glicerol como fonte de carbono, todos positivos e reação de hipersensibilidade positivo em tomate, fumo e couve (SCHAAD et al. Laboratory guide for identification of plant pathogenic bacteria. St. Paul. APS, 2001, p.56-72). A bactéria foi confirmada por PCR, com o par de primers específico B162t7/B162r amplificando um fragmento de $700 \mathrm{pb}$ (Figura 1C) (BARAK et al. Plant Disease, v.85, n.2, p.169-178, 2001). Para o teste de patogenicidade, cinco plantas de alface cultivar "Simpson" foram inoculadas por pulverização, com uma suspensão bacteriana de $10^{9} \mathrm{UFC} \mathrm{mL}^{-1}\left(\mathrm{OD}_{550}=0,5\right)$ nas folhas. Como controle, plantas foram pulverizadas com solução

salina $0,85 \%$. As plantas permaneceram em câmara úmida por 24 $\mathrm{h}$ antes e após a inoculação e mantidas em casa de vegetação. Após 3 dias foram reproduzidos os sintomas de lesões encharcadas e translúcidas, confirmando a mancha bacteriana nas folhas da alface (Figura 1B), de onde a bactéria foi reisolada. Nas plantas controle não foram observados sintomas. As características permitiram identificar a bactéria como Xanthomonas campestris pv. vitians, agente causal da mancha bacteriana em folhas da alface. Xanthomonas campestris pv. vitians (Brown 1918) Dye 1978 (VAUTERIN et al. International Journal of Systematic Bacteriology, v.45, p.472-489, 1995) é representada por duas populações bacterianas genotípica e fenotipicamente distintas; onde o isolado tipo (patotipo) refere-se à Xanthomonas axonopodis pv. vitians (Brown 1918) Vauterin et al. 1995. No Brasil, a doença foi relatada nas regiões Centro-Oeste, Sul, Sudeste e nos Estados de São Paulo, Rio de Janeiro e Distrito Federal (MALAVOTA JR. et al. Summa Phytopathologica, v.34, s.suppl., 2008). A bactéria dissemina-se rapidamente em casa de vegetação, por meio da água de irrigação (WELLMAN-DESBIANS, Phytopathology, v. 89 , p. S84, 1999). A caracterização e identificação dessa patovar auxiliará no manejo adequado da doença, em casa de vegetação e no campo. Este é o primeiro relato de $X$. campestris pv. vitians causando mancha em folhas da alface em Minas Gerais. O isolado encontrase depositado na coleção de fitobactérias do Instituto de Ciências Agrárias da Universidade Federal de Uberlândia, com o código UFU E125.

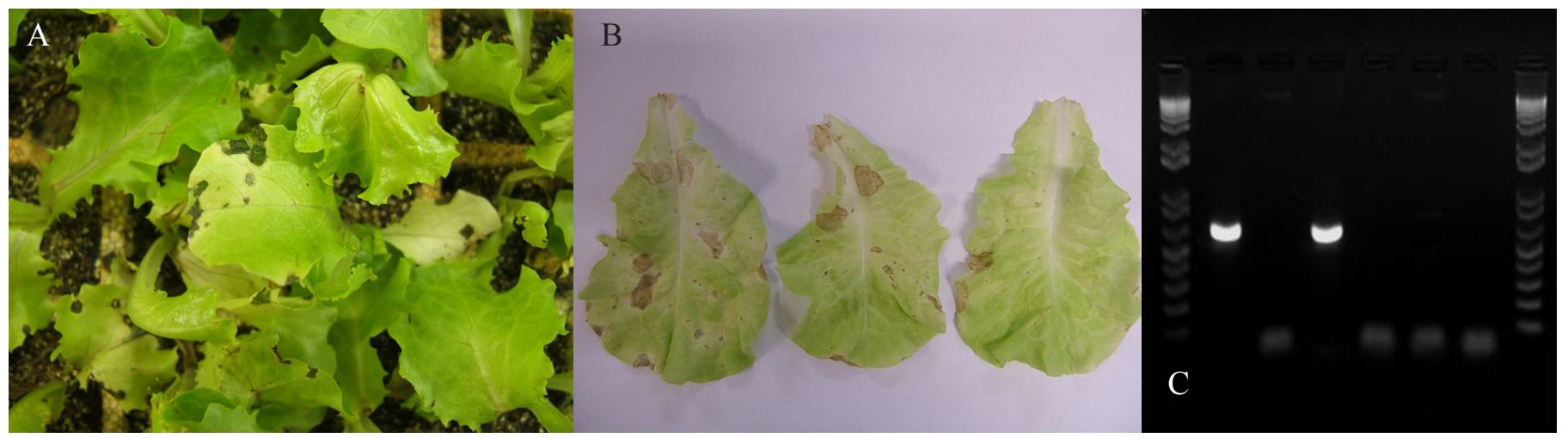

Figura 1. Sintomas de mancha bacteriana em folhas de alface (A), em bandejas em casa de vegetação e 5 dias após a inoculação (B); causados por Xanthomonas campestris pv. vitians. (C) Amplificação de um fragmento de $700 \mathrm{pb}$ de X. campestris pv. vitians pelos iniciadores B162, em gel de agarose por PCR; M (marcador molecular, 1 kb plus), 1 (controle positivo, DNA de isolado padrão), 2 (isolado UFU E125). 